\title{
Rancang Bangun Alat Cetak Briket Berbahan Dasar Kotoran Sapi
}

\author{
Rinasa Agistya Anugrah', Andika Wisnujati \\ Program Studi Teknologi Mesin, Universitas Muhammadiyah Yogyakarta, Yogyakarta ${ }^{12}$ \\ email $^{1}$ : rinasaanugrah@umy.ac.id
}

\begin{abstract}
Abstrak
Kotoran ternak dapat dimanfaatkan untuk sesuatu yang lebih berharga seperti pupuk organik dan energi alternatif. Kotoran ternak termasuk kotoran sapi dapat dimanfaatkan sebagai pembuatan briket. Pembriketan merupakan salah satu solusi dalam pemanfaatan kotoran ternak. Untuk membuat briket diperlukan alat pencetak manual yang dapat dioperasikan oleh satu orang. Penelitian dimulai dengan perancangan alat menggunakan Software Autodesk Invertor Profesional 2015. Tujuan perancangan ini supaya dihasilkan alat pencetak briket yang praktis dan sederhana namun tetap kuat menopang daya tekan operator. Alat pencetak briket ini memiliki bentuk yang simple dan mudah dipindah dan tidak memakan banyak tempat. Setelah alat cetak briket selesai dirancang kemudian dilanjutkan pada tahap pembuatan alat tersebut. Dimulai dari memotong bahan, mengelas kemudian merakit semua bagian-bagian. Kemudian dilakukan pengujian fungsional dan dilanjutkan ke proses pembuatan briket. Alat cetak briket manual ini dapat menghasilkan 4 buah briket silinder dengan waktu 25 detik/cetakan dan dapat menghasilkan 28,48 kg briket per jam. Kadar air pada briket-briket tersebut adalah sebesar $25,4 \%$. Selain itu alat pencetak briket ini memiliki dimensi ukuran tinggi $40 \mathrm{~cm}$ panjang $25 \mathrm{~cm}$ dan lebar $15 \mathrm{~cm}$, dengan begitu alat ini mudah di pindah-pindah.
\end{abstract}

Kata kunci: rancang bangun, alat cetak briket, briket, kotoran sapi, Autodesk Inventor

\begin{abstract}
Animal manure can be used for something more valuable, such as organic fertilizers and alternative energy. Livestock manure, including cow manure, can be used as briquettes. Briquette is a solution in the use of livestock manure. To make briquettes, a manual printer that can be operated by one person is required. The research began with designing a tool using Autodesk Invertor Professional 2015 Software. The aim of this design was to produce a briquette printer that was practical and simple but still strong to support the operator's compressive power. This briquette printer has a simple shape and is easy to move and doesn't take up much space. After the briquette molding tool has been designed, it is then continued at the manufacturing stage of the tool. Starting from cutting the material, welding then assembling all the parts. Then carried out functional testing and proceed to the process of making briquettes. This manual briquette press can produce 4 cylindrical briquettes in 25 seconds / mold and can produce $28.48 \mathrm{~kg}$ of briquettes per hour. The water content in the briquettes was $25.4 \%$. In addition, this briquette printer has dimensions of height $40 \mathrm{~cm}$, length $25 \mathrm{~cm}$ and width of $15 \mathrm{~cm}$, so this tool is easy to move around.
\end{abstract}

Keywords: design, briquette molding equipment, briquette, cow manure, Autodesk Inventor

\section{PENDAHULUAN}

Penelitian tentang biomassa telah banyak dikembangkan oleh para peneliti hingga saat ini. Briket yang biasanya terbuat dari batu bara (energi fosil), kini telah dikembangkan yaitu dengan mensubtitusi bahan bakunya menjadi bahan baku yang dapat diperbarui atau bahan baku bio yang dikenal sebagai briket bio. Briket bio merupakan salah satu produk biomassa yang dimanfaatkan sebagai bioenergi yang telah dikembangkan oleh beberapa peneliti. Bahan baku briket bio atau yang dikenal dengan biobriket adalah dari suatu bahan organik dan atau campuran dari dua atau lebih bahan organik (Pambudi et al., 2018; Putri \& Andasuryani, 2017; Rinanda et al., 2021; Yuliah et al., 2017). 
Kotoran ternak adalah salah satu bahan biomassa yang merupakan limbah yang mudah di temukan di sekitar kita, khususnya di daerah pedesaan. Kotoran ternak seperti halnya pada kotoran sapi memiliki banyak kandungan seperti Nitrogen, Phosphor, Kalium, Kadar Air dan beberapa unsur lain seperti $\mathrm{Ca}, \mathrm{Mg}, \mathrm{Mn}, \mathrm{Fe}, \mathrm{Cu}, \mathrm{Zn}, \mathrm{Ni}$ (Dewi et al., 2017). Kotoran ternak dapat dimanfaatkan untuk sesuatu yang lebih berharga seperti pupuk organik (Dewi et al., 2017) dan energi alternatif (Purwanta \& Daniel, 2018).

Salah satu inovasi pemanfaatan kotoran ternak adalah pembuatan briket. Kotoran ternak seperti kotoran sapi dapat dimanfaatkan sebagai bahan bakar briket. Briket merupakan bahan bakar pengganti minyak tanah dan gas LPG yang terbuat dari sampah, limbah pertanian ataupun limbah perternakan. Pembuatan briket dilakukan dengan mengubah kotoran sapi yang sudah dicampur bahan perekat ke dalam bentuk silinder, kubus atau sesuai keinginan dengan menggunakan alat cetak. Briket yang telah dicetak kemudian dikeringkan dengan cara dijemur.

Tujuan penelitian ini adalah merancang alat cetak briket sederhana dan praktis dengan Software Autodesk Invertor Professional 2015. Alat cetak briket sederhana ini dioperasikan secara manual. Diperlukan sekali menekan tuas ke bawah guna mengepres adonan briket menjadi empat briket silinder. Keuntungan dari penggunaan alat ini adalah pemilik hewan ternak sapi dapat memanfaatkan kotoran ternaknya untuk dibuat briket sebagai bahan bakar alternatif. Pembuatan alat ini juga tidak terlalu banyak mengeluarkan biaya karena tidak memakai mesin hanya menggunakan tangan manusia untuk menggerakannya.

\section{TINJAUAN PUSTAKA}

Briket dapat dibuat dari bermacam-macam bahan bekas atau tidak terpakai seperti ampas batang tebu dan serbuk gergaji yang sudah diteliti nilai kalor dari briket tersebut (Wibowo, 2019). Terdapat juga penelitian lain yang menggunakan cangkang kelapa sawit (Rantawi, 2019), mereka meneliti beberapa parameter penting yaitu nilai kalor, kadar air, kadar abu, waktu bakar. Hasilnya jika dibandingkan dengan SNI briket arang tersebut dapat disimpulkan lebih baik kualitasnya, juga tempurung kelapa (Norhikmah et al., 2021), serta campuran tempurung kelapa dan arang sekam padi (Yuliah et al., 2017) sebagai bahan baku briket. Terdapat juga yang menggunakan bahan baku briket dari limbah kayu (Pambudi et al., 2018; Rinanda et al., 2021; Satmoko et al., 2013; Sugiyati et al., 2021), serbuk gergaji (Sari \& Jurusan, 2020), serbuk gergaji dan lumpur IPAL (Mirwan \& F, 2020), campuran arang kayu dan ampas tebu (Elfiano et al., 2014), arang pelepepah aren (Pane et al., 2015), arang tempurung pala (Patandung, 2014), campuran limbah baglog jamur tiram dan sekam padi (Kurniawan \& Syukron, 2019).

Bahan dasar atau bahan baku briket dari kotoran sapi sudah pernah diteliti oleh peneliti sebelumnya yaitu dengan menggunakan bahan tambah perekat tepung tapioka (Purwanta \& Daniel, 2018). Hasil yang terbaik adalah pada variasi penambahan tapioka sebesar $1 \%$ dan kotoran sapi 99\%. Menurut mereka perlakuan penambahan bahan perekat tepung tapioka pada briket kotoran sapi tidak berpengaruh signifikan terhadap kadar air hilang, nilai kalor, dan kadar abu. Hal ini terjadi karena penambahan bahan perekat dilakukan dalam kadar yang jumlahnya sedikit yaitu maksimal $7 \%$ dari bahan baku total. Sehingga bahan perekat tepung tapioca ini bisa dijadikan rujukan sebagai penguat briket karena memiliki daya rekat yang baik dalam penelitian ini.

\section{METODE PENELITIAN}

Berikut Gambar 1 di bawah adalah diagram alir (flow chart) pada penelitian ini:

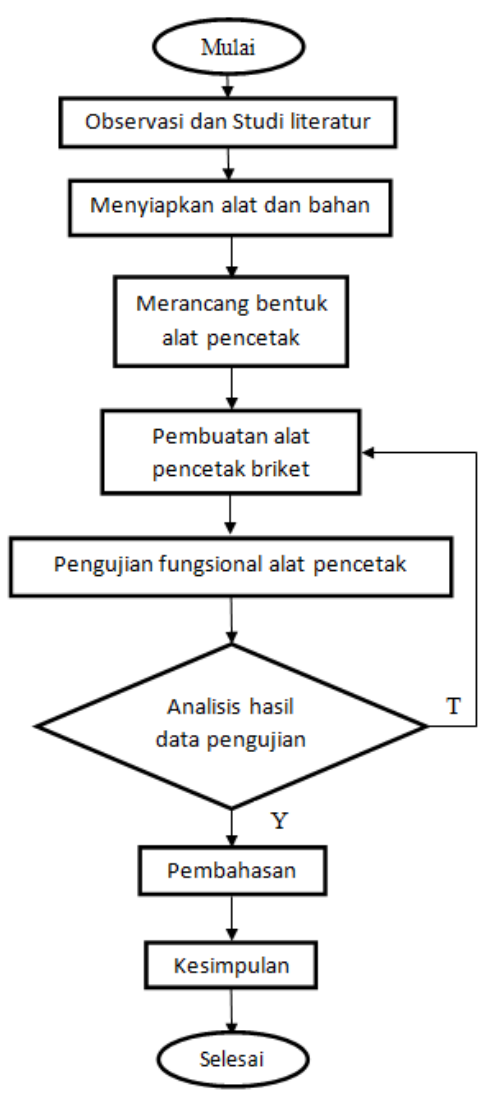

Gambar 1. Diagram Alir (Flow Chart) Penelitian
Alat dan Bahan
Alat
1. Software Autodesk Invertor Professional 2015
2. Gerinda Tangan
3. Gerinda Potong Duduk
4. Las Listrik SMAW
5. Bor Bangku 
6. Plat Besi

7. Pipa Besi

8. Sikat Kawat

Bahan

1. Ring Besi

2. Besi Plat Strip

3. Besi Beton

4. Baut \& Mur

\section{Mekanisme Pembuatan}

Mekanisme pembuatan alat cetak briket ini melalui beberapa tahapan berikut ini:

1. Perancangan menggunakan metode CAD (Computer Aided Design) dengan Software Autodesk Inventor Profesional 2015.

2. Mendesain bentuk landasan dan tiang penyangga cetakan.

3. Dilanjutkan mendesain bentuk penekan cetakan.

4. Kemudian mendesain bentuk lengan ayun.

5. Mendesain bentuk tuas penekan cetakan.

\section{Pembuatan Alat Pencetak Briket Berbahan Dasar Kotoran Sapi}

Tahapan proses pembuatan alat pencetak briket berbahan dasar kotoran sapi adalah sebagai berikut:

1. Memilih dan Memotong bahan (material) sesuai dengan ukuran yang telah di tentukan menggunakan gerinda (Gambar 2a dan 2b).

2. Membuat lengan ayun dengan memotong plat besi sesuai pola dan membuat lubang baut dengan bor bangku.

3. Melakukan pengelasan pada plat landasan dan tiang penyangga, kemudian dilakukan pembersihan kerak las.

4. Melubangi landasan sejumlah 4 lubang dengan bor bangku.

5. Mengelas besi beton pada lubang landasan kemudian bersihkan kerak las.

6. Mengelas pipa penyangga dengan plat penekan cetakan, kemudian bersihkan kerak las.

7. Mengelas plat penekan cetakan dan pipa penelan, kemudian mengelas ring besi pada ujung pipa penekan, dan dirangkai pada tiang penyangga.

8. Mengelas penahan tuas penekan pada tiang penyangga.

9. Memotong besi plat strip untuk membuat tuas penekan dengan gerinda tangan, kemudian mengebor ujung besi plat strip dengan bor bangku untuk tempat baut (Gambar 2c).

10. Merakit semua bagian dengan baut dan mur, kemudian melakukan uji fungsional.

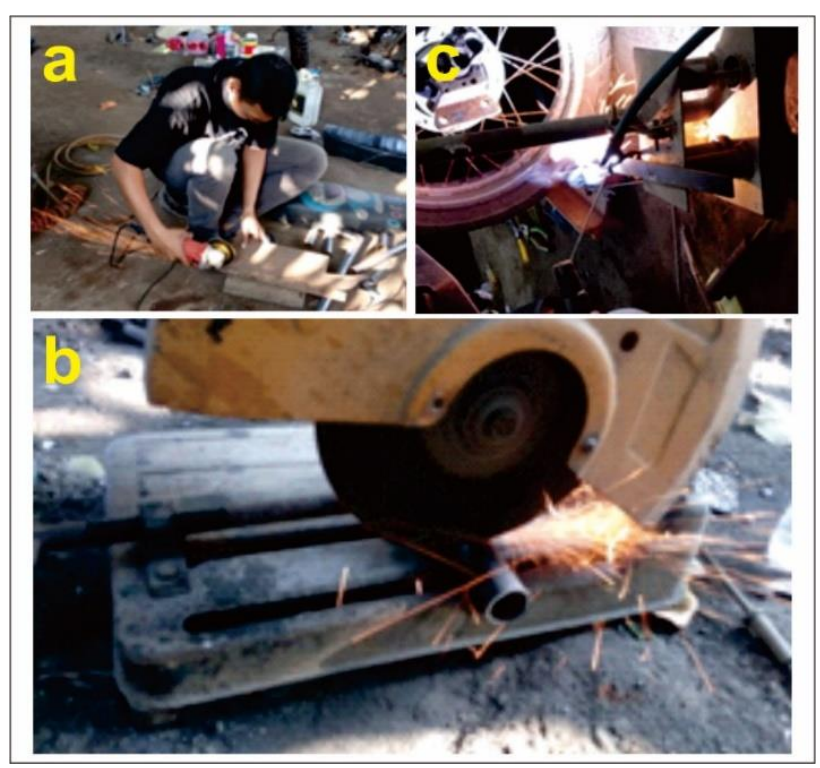

Gambar 2a. Pemotongan Plat Besi dengan Gerinda Tangan, 2b. Pemotongan Pipa Besi dengan Gerinda Potong Duduk, 2c. Pengelasan Tuas Penekan

\section{Metode Analisis Hasil Data Pengujian}

Metode perhitungan kapasitas pencetakan briket dalam waktu satu jam adalah dengan persamaan berikut:

$$
\mathrm{Kp}=B b / T
$$

dengan:

$\mathrm{Kp}=$ kapasitas pengepresan $(\mathrm{kg} / \mathrm{jam})$

$\mathrm{Bb}=$ berat briket yang dihasilkan $(\mathrm{kg})$

$\mathrm{T}=$ waktu pengepresan (jam)

Sedangkan metode perhitungan kadar air pada briket adalah sebagai berikut:

$$
\text { Kadar Air }(\%)=\frac{B-C}{B} x 100 \%
$$

dengan:

$\mathrm{B}=$ berat briket sebelum dioven (gr)

$\mathrm{C}=$ berat briket setelah dioven (gr)

\section{HASIL DAN PEMBAHASAN Perancangan}

Perancangan merupakan tahap awal dari rancang bangun suatu alat, adapun yang dilakukan diantaranya adalah menentukan desain, pemilihan material yang digunakan, dan melakukan langkahlangkah proses pembuatan. Dalam proses perancangan perangkat lunak yang digunakan untuk menggambar desain yaitu Autodesk Invertor Professional 2015. Setelah melewati proses perancangan maka dapat dilanjutkan ke tahap pembuatan alat cetak (press) briket. Hasil perancangan atau desain alat cetak briket ini terlihat pada Gambar 3a, 3b, dan 3c. Sedangkan dimensi atau ukuran dari alat ini beserta part atau komponennya diperlihatkan pada Gambar 4. 


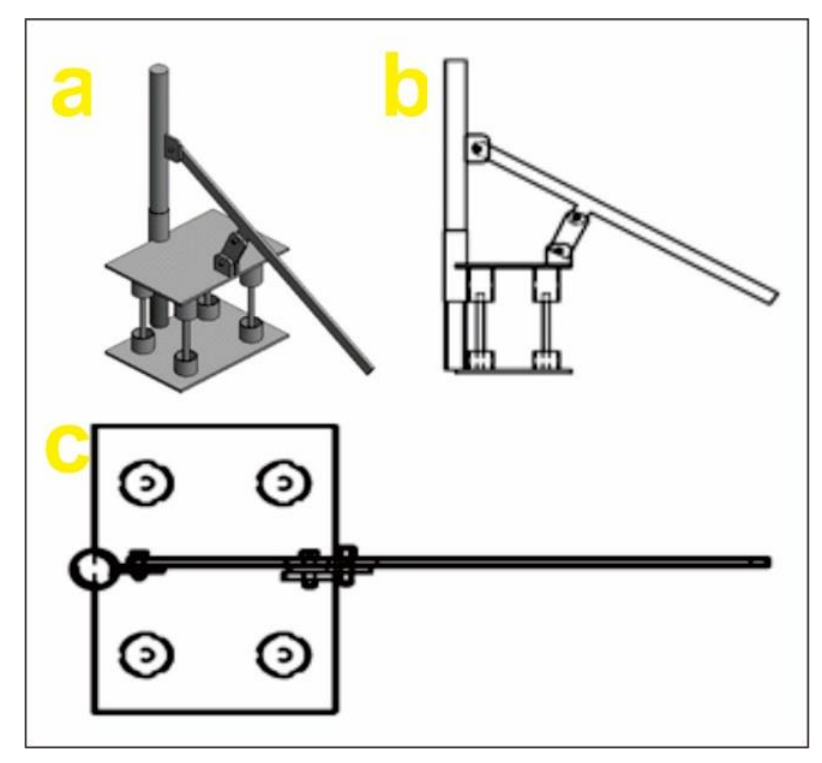

Gambar 3a. Desain Alat Cetak Briket Berbahan Dasar Kotoran Sapi 3D (Isometri), 3b. Desain alat 2D tampak samping, 3c. Desain alat 2D tampak atas
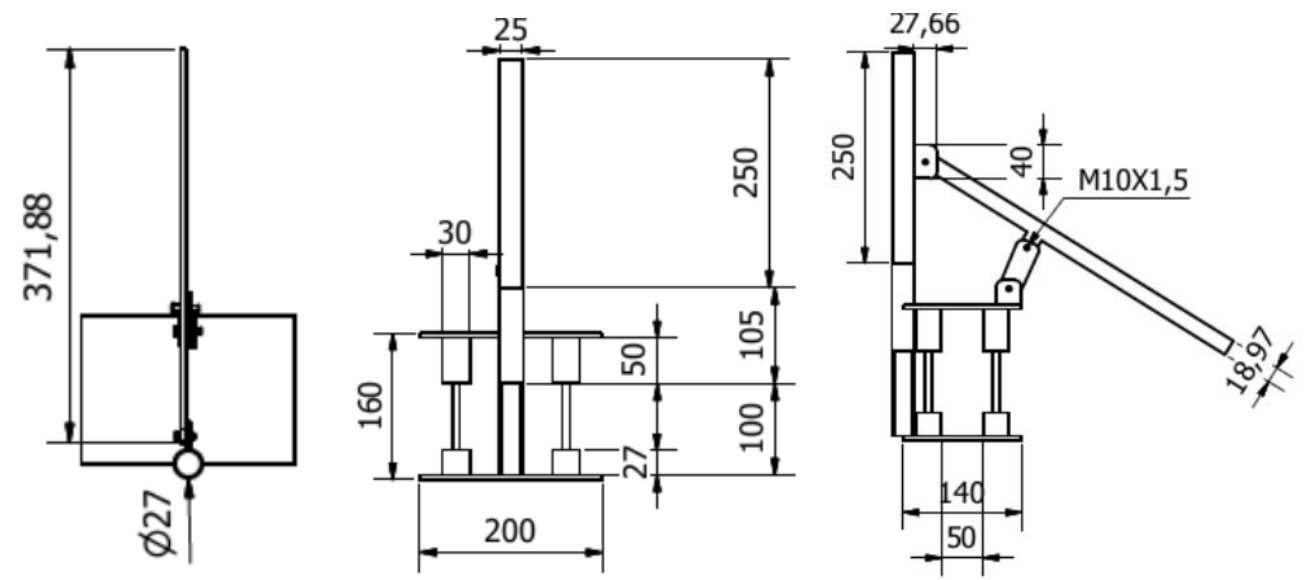

Gambar 4. Dimensi Desain Alat Cetak Briket Berbahan Dasar Kotoran Sapi: Tampak Atas, Depan, dan Samping

\section{Hasil Perancangan dan Assembly Alat}

Rangka penopang menggunakan pipa besi berdiameter $3 \mathrm{~cm}$, dengan alas cetakan besi plat panjang $25 \mathrm{~cm}$, lebar $14 \mathrm{~cm}$, dan tebal $2 \mathrm{~mm}$. sedangkan bagian tengah cetakan diberi besi silinder ukuran panjang $10 \mathrm{~cm}$ dan berdiameter $1 \mathrm{~cm}$ agar briket yang dihasilkan mempunyai rongga ditengahnya.

Cetakan alat ini menggunakan pipa besi dengan diameter lubang $34 \mathrm{~mm}$ sedangkan untuk penekan briket menggunakan pipa besi berdiameter $30 \mathrm{~mm}$, panjang $5 \mathrm{~cm}$ dan ujungnya ditempel ring besi dengan diameter lubang $11 \mathrm{~mm}$, serta penekan tersebut ditempel pada plat besi sepanjang $20 \mathrm{~cm}$ dan lebar $14 \mathrm{~cm}$. Lengan ayun berbahan besi plat strip panjang $25 \mathrm{~cm}$, lebar $25 \mathrm{~mm}$, dan tebal $5 \mathrm{~mm}$. Tuas penekan berbahan besi plat strip panjang $35 \mathrm{~cm}$, lebar $25 \mathrm{~mm}$, dan tebal $5 \mathrm{~mm}$. Dalam proses pembuatannya banyak menggunakan alat potong dan mesin las.
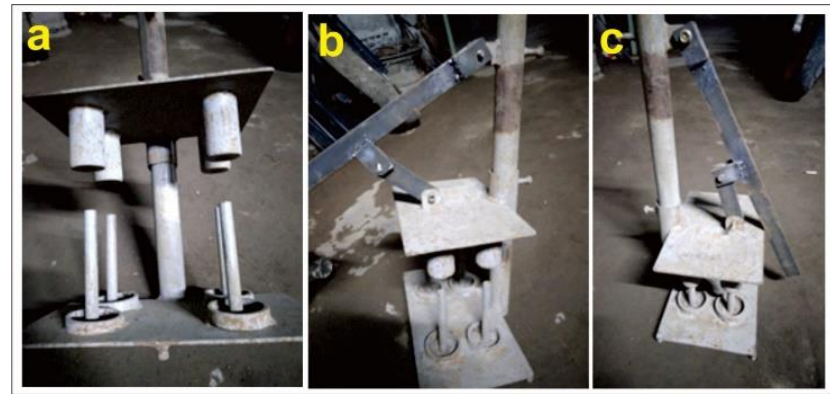

Gambar 5a. Alat pres tampak depan, 5b. alat pres tampak samping, 5c. alat pres tampak samping

\section{Pembuatan Briket \\ Persiapan Bahan Baku}

Bahan baku berupa kotoran sapi yang sudah kering dan tepung tapioka sebagai perekat. Kotoran sapi dijemur selama 2 hari untuk mengurangi kadar air (Gambar 6a). Kotoran sapi yang sudah kering dilakukan penumbukan hingga halus dan diayak dengan ayakan 25 mesh, sehingga diperoleh sebuk kotoran sapi sebanyak 500 gr (Gambar 6b dan 6c). 
Kemudian mencampurkan kedua bahan tersebut dengan komposisi kotoran sapi $99 \%$ dan tapioka $1 \%$ berdasarkan penelitian yang telah dilakukan peneliti sebelumnya (Purwanta \& Daniel, 2018)

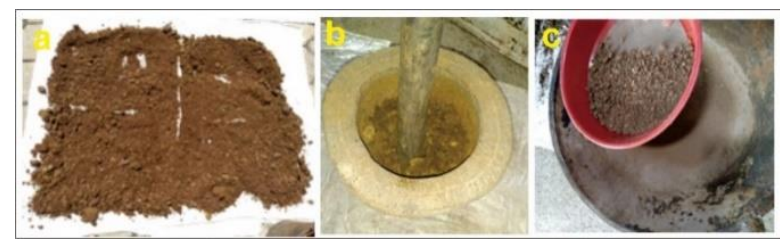

Gambar 6a. Penjemuran kotoran sapi, 6b. Proses penumbukkan, 6c. Proses Pengayakan

\section{Pembuatan Adonan Briket}

Proses pembuatan adonan briket yaitu dengan membuat perekat dengan mencampur tapioka sebanyak 5 gr dan air $250 \mathrm{ml}$, kemudian mengaduk dan memanaskan di atas kompor hingga mengental (Gambar 7a). Langkah berikutnya mencampurkan perekat dengan kotoran sapi lalu diaduk (Gambar 7b dan 7c).

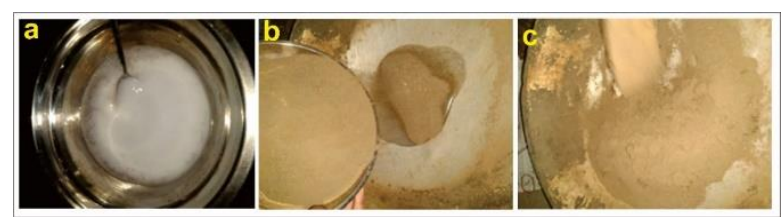

Gambar 7a. Pembuatan perekat tepung tapioca,

7b. Pencampuran serbuk kotoran sapi dan perekat, 7c. Proses Pengadukan

\section{Pencetakan Briket}

Langkah pertama adalah dengan memasukkan hasil campuran kedua bahan pada cetakan berbentuk silinder dengan diameter $3 \mathrm{~cm}$ dan panjang $10 \mathrm{~cm}$, dan dilakukan pengepresan (Gambar 8a). Untuk mengisi satu cetakan diperlukan waktu selama 5 detik sehingga di perlukan waktu 20 detik untuk semua cetakan. Kemudian dilakukan pengepresan selama 5 detik (Gambar 8b dan 8c), sekali cetak menghasilkan 4 buah briket dan dengan berat 712 gr. Kapasitas pencetakan briket per jam ada sebagai berikut:

$$
\begin{array}{ll}
\mathrm{Kp} & =B b / T=0.712 \mathrm{gr} / 0.025 \mathrm{jam} \\
& =28.48 \mathrm{~kg} / \mathrm{jam}
\end{array}
$$

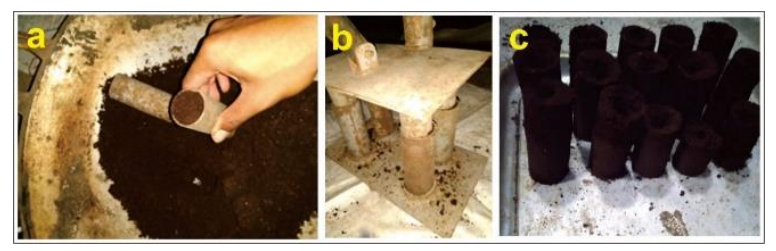

Gambar 8a Pengisian Cetakan, 8b Pengepresan Adonan Briket, 8c Briket Hasil Pencetakan

\section{Pengeringan}

Briket yang sudah di cetak dikeringkan dengan cara di oven untuk menurunkan kadar air pada briket, dan di oven selama 1 jam dengan api sedang seperti yang ditunjukkan pada Gambar 9 .

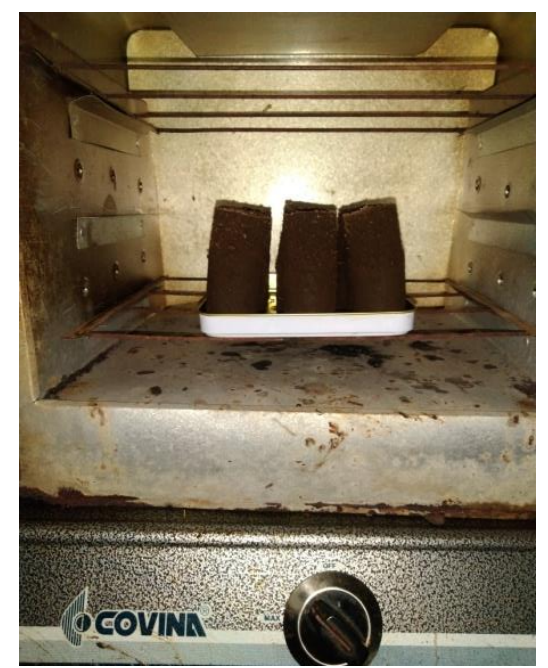

Gambar 9. Proses Pengovenan Briket

\section{Pengujian Briket}

Pengujian dimaksudkan guna mengetahui apakah briket yang dihasilkan berkualitas bagus yang layak di gunakan dan dipasarkan. Pengujian berupa kadar air, kadar abu, nilai kalor, dan laju pembakaran. Pada penelitian ini hanya dilakukan satu pengujian yaitu kadar air. Hal tersebut disebebkan karena briket tidak dapat terbakar sempurna saat disulut dengan api. Api yang dihasilkan berupa bara api selama 1520 menit dan menghabiskan $1 / 4$ bagian briket saja (Gambar 10). Sedangkan untuk kepadatan dan kekuatan masih kurang. Setelah dioven selama 1 jam, dilakukan penimbangan dan dihasilkan briket basah yang awalnya 712 gr menjadi 531 gr, sehingga kadar airnya adalah sebagai berikut:

$$
\begin{aligned}
& \text { Kadar air }(\%)=\frac{B-C}{B} \times 100 \% \\
& \frac{712 g r-531 g r}{712 g r} \times 100 \%=25.4 \%
\end{aligned}
$$

dengan:

$\mathrm{B}=$ massa briket sebelum dioven $(\mathrm{gr})$

$\mathrm{C}=$ massa briket setelah dioven $(\mathrm{gr})$

Berikut ini adalah kondisi secara visual briket yang telah dibakar terlihat pada Gambar 10 di bawah. 


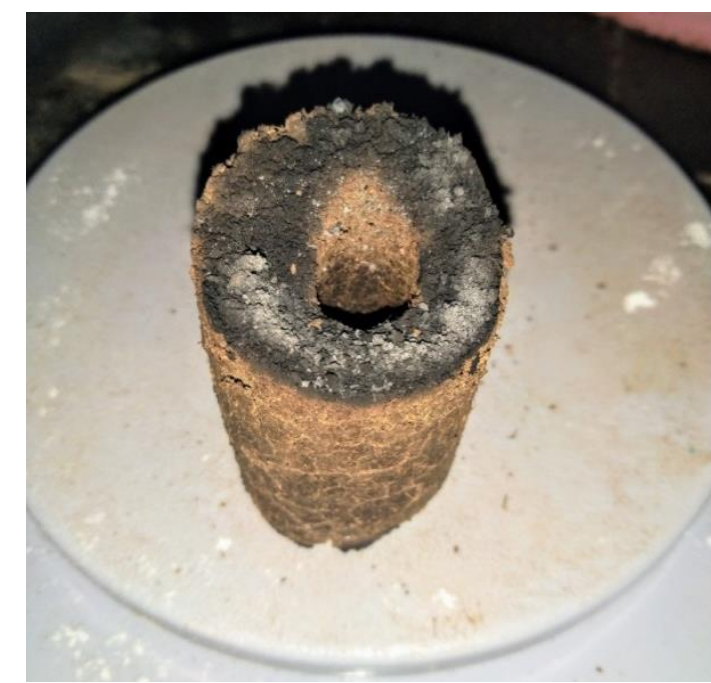

Gambar 10. Kondisi Briket Sesudah Dibakar

\section{SIMPULAN}

Berdasarkan data yang diperoleh dari penelitian di atas dapat disimpulkan :

1. Bahan yang digunakan pipa besi diameter $34 \mathrm{~mm}$ panjang $25 \mathrm{~cm}$ dan diameter $30 \mathrm{~mm}$ panjang 60 $\mathrm{cm}$, besi platstrip $80 \mathrm{~cm} \times 2,5 \mathrm{~cm}$, besi plat $25 \mathrm{~cm}$ x $14 \mathrm{~cm}$ dan $20 \mathrm{~cm} \times 14 \mathrm{~cm}$, dan besi beton diameter $10 \mathrm{~mm}$ panjang $40 \mathrm{~cm}$.

2. Desain yang dihasilkan memiliki dimensi ukuran tinggi $40 \mathrm{~cm}$, panjang $25 \mathrm{~cm}$, dan lebar $15 \mathrm{~cm}$.

3. Dengan dimensi panjang, lebar, dan tinggi seperti tersebut di atas, alat ini mudah diangkat, dipindah, dan tidak memakan banyak ruang.

4. Alat cetak briket manual ini dapat menghasilkan 4 buah briket silinder dengan waktu 25 detik/cetakan dan dapat menghasilkan 28,48 kg briket per jam dengan kadar air pada briket-briket tersebut adalah sebesar $25,4 \%$.

5. Ketika pengujian fungsional, alat bekerja kurang maksimal yang disebabkan karena tekanan saat pengepresan kurang merata sehingga proses naik turun penekan kurang lancar dan juga adanya sedikit kendala sebelum pengepresan yaitu operator harus memosisikan lubang penekan pada besi yang berada di tengah cetakan.

\section{UCAPAN TERIMAKASIH}

Ucapan terima kasih penulis sampaikan kepada Muh. Fajar Adnan Dhali, alumni Program Studi Teknologi Mesin, Program Vokasi, Universitas Muhammadiyah Yogyakarta yang telah membantu dalam perakitan alat dan pengambilan data dalam penelitian ini.

\section{DAFTAR PUSTAKA}

Dewi, N. M. E. Y., Setiyo, Y., \& Nada, I. M. (2017). Pengaruh Bahan Tambahan Pada Kualitas Kompos Kotoran Sapi. Jurnal BETA (Biosistem Dan Teknik Pertanian), 5(1), 76-82.
Elfiano, E., Subekti, P., \& Sadil, A. (2014). Analisa Proksimat dan Nilai Kalor Pada Briket Bioarang Limbah Ampas Tebu dan Arang Kayu. Jurnal Aptek, 6(1), 57-64.

Kurniawan, F. A., \& Syukron, A. A. (2019). Karakteristik Briket Bioarang dari Campuran Limbah Baglog Jamur Tiram (Pleurotus Ostreatus) dan Sekam Padi. Indonesian Journal of Applied Physics, 9(02), 76-83. https://doi.org/10.13057/ijap.v9i2.34478

Mirwan, M., \& F, I. M. (2020). Pemanfaatan Lumpur IPAL dan Serbuk Gergaji Menjadi Briket Alternatif. Jurnal Envirotek, 12(2), 59-63.

Norhikmah, Sari, N. M., \& Mahdie, M. F. (2021). Pengaruh Persentase Perekat Tapioka Terhadap Karakteristik Briket Arang Tempurung Kelapa. Jurnal Sylva Scienteae, 04(2), 324-333.

Pambudi, F. K., Nuriana, W., \& Hantarum. (2018). Penurunan Nilai Kadar Air Dan Laju Pembakaran Pada Biobriket Limbah Kayu Sengon Dengan Variasi Tekanan. JURNAL AGRI-TEK: Jurnal Ilmu Pertanian, Kehutanan Dan Agroteknologi, 19(2), 92-95. https://doi.org/10.33319/agtek.v19i2.26

Pane, J. P., Junary, E., \& Herlina, N. (2015). Pengaruh Konsentrasi Perekat Tepung Tapioka dan Penambahan Kapur dalam Pembuatan Briket Arang Berbahan Baku Pelepah Aren ( Arenga pinnata ). Jurnal Teknik Kimia, 4(2), $32-38$.

Patandung, P. (2014). Pengaruh Jumlah Tepung Kanji Pada Pembuatan Briket Arang Tempurung Pala. Jurnal Penelitian Teknologi Industri, 6(2), 95102. https://doi.org/10.33749/jpti.v6i2.3195

Purwanta, \& Daniel, N. (2018). Kajian Pembuatan Briket Limbah Ternak Sapi (Biltes) Dengan Perekat Tepung Tapioka. Jurnal Triton, 9(2), $36-44$.

Putri, R. E., \& Andasuryani. (2017). Studi Mutu Briket Arang Dengan Bahan Baku Limbah Biomassa. Jurnal Teknologi Pertanian Andalas, 21(2), 143-151. https://doi.org/10.25077/jtpa.21.2.143151.2017

Rantawi, A. B. (2019). Mengetahui Kualitas Briket Cangkang Kelapa Sawit Menggunakan Perekat Arpus sebagai Energi Alternatif. Jurnal Citra Widya Edukasi, 11(3), 217-222. http://journal.cwe.ac.id/index.php/jurnal_citra widyaedukasi/article/view/203

Rinanda, A. D., Nuriana, W., \& Sutrisno. (2021). Pengaruh Variasi Tekanan Terhadap Kerapatan, Kadar Air dan Laju Pembakaran Pada Biobriket Limbah Kayu Mahoni. PILAR TEKNOLOGI: Jurnal Ilmiah Ilmu-Ilmu Teknik Website, 6(1), 21-24. 
Sari, P. N., \& Jurusan, S. A. (2020). Pemanfaatan Serbuk Gergaji Sebagai Bahan Baku Briket. Media Eksakta, 16(2), 98-104. https://doi.org/10.1016/j.tmaid.2020.101607\% 0Ahttps://doi.org/10.1016/j.ijsu.2020.02.034\% 0Ahttps://onlinelibrary.wiley.com/doi/abs/10.1 111/cjag.12228\%0Ahttps://doi.org/10.1016/j.ss ci.2020.104773\%0Ahttps://doi.org/10.1016/j.ji nf.2020.04.011\%0Ahttps://doi.o

Satmoko, M. E. A., Saputro, D. D., \& Budiyono, A. (2013). Karateristik Briket dari Limbah Pengolahan Kayu Sengon dengan Metode Cetak Panas. Journal of Mechanical Engineering Learning, 2(1), 1408-1412.

Sugiyati, F. Y., Sutiya, B., \& Yuniarti. (2021). Karakteristik Briket Arang Campuran Arang Akasia Daun Kecil (Acacia auliculiformis) dan Arang Alaban (Vitex pubescens vhal). Jurnal Sylva Scienteae, 04(2), 274-284.

Wibowo, R. (2019). Analisis Thermal Nilai Kalor Briket Ampas Batang Tebu dan Serbuk Gergaji. Rekayasa Mesin, 10(1), 9-15.

Yuliah, Y., Suryaningsih, S., \& Ulfi, K. (2017). Penentuan Kadar Air Hilang dan Volatile Matter Pada Bio-Briket dari Campuran Arang Sekam Padi dan Batok Kelapa. Jurnal Ilmu Dan Inovasi Fisika, 1(1), 51-57. https://doi.org/10.24198/jiif.v1n1.7 